\title{
Detection of Salmonella spp. and diarrheagenic Escherichia coli in fresh pork sausages
}

\section{Pesquisa de Salmonella spp. e Escherichia coli diarreiogênica em linguiças suínas frescas}

\author{
Paola Bianca Barbosa Cavalin¹; Juan Josue Puño Sarmiento²; Renata Katsuko \\ Takayama Kobayashi ${ }^{3}$; Gerson Nakazato ${ }^{3}$; Armando Navarro Ocaña ${ }^{4}$; Tereza \\ Cristina Rocha Moreira Oliveira ${ }^{5 *}$
}

\begin{abstract}
The presence of pathogenic microorganisms in meat products may result in foodborne diseases and economic losses to their producers. Small industries in the region of Londrina, Paraná, produce sausages that are commercialized in free fairs, small markets, bars, and restaurants in the city. Although these industries are inspected by the Municipal Inspection Service of Londrina, there are no data about the pathogenic microorganisms present in these products. The objective of this study was to investigate the presence of Salmonella spp. in sausages produced and sold in the region of Londrina, Paraná, and identify eae, bfp, stx1, stx2, hlyA, ipaH, elt, est, aggR, aap, and AA probe genes in Escherichia coli strains isolated from these samples. Forty-six samples of three types of sausages (fresh pork, Tuscan, and Calabresa) produced by four different producers (brands A, B, C, and D) were analyzed. Salmonella spp. was isolated from 13 (28.3\%) and E. coli from 33 (71.3\%) of the analyzed samples. Seven (53.8\%) of 13 samples contaminated with Salmonella spp. were from brand A. Salmonella spp. contamination was the highest in the Tuscan sausage samples $(8 / 17,41.7 \%)$ when compared with the fresh pork sausage samples of all brands analyzed. E. coli was isolated from 12 of 13 samples contaminated with Salmonella spp. One sample of Calabresa sausage was contaminated with atypical enteropathogenic $E$. coli serotype O108:H9 that has the eae and $h l y A$ genes. The results suggest contamination of the processing plant and/or raw meat used in the manufacture of sausages. A better inspection of the industries is required to ensure that Good Manufacturing Practices are followed by which the contamination of products by pathogenic bacteria can be prevented.
\end{abstract}

Key words: Pork meat. Enteropathogenic bacteria. Virulence genes.

1 Discente de Mestrado, Programa de Pós-Graduação em Ciência de Alimentos, Universidade Estadual de Londrina, UEL, Londrina, PR, Brasil. E-mail: paola.bbc@gmail.com

2 Discente de Doutorado, Programa de Pós-Graduação em Microbiologia, UEL, Londrina, PR, Brasil. E-mail: juanpunosarmiento@ gmail.com

3 Profs. Drs., Programa de Pós-Graduação em Microbiologia, Departamento de Microbiologia, UEL, Londrina, PR, Brasil. E-mail: kobayashirkt@uel.br; gnakazato@uel.br

4 Prof. Dr., Departamento de Salud Pública, Facultad de Medicina, Universidad Nacional Autónoma de México, México. E-mail: arnava@unam.mx

5 Prof ${ }^{\mathrm{a}} \mathrm{Dr}^{\mathrm{a}}$, Programa de Pós-Graduação em Ciência de Alimentos, Departamento de Ciência e Tecnologia de Alimentos, UEL, Londrina, PR, Brasil. E-mail: terezaoliveira@yahoo.com

* Author for correspondence 


\section{Resumo}

A presença de microrganismos patogênicos em produtos cárneos pode levar a doenças de origem alimentar e perdas econômicas aos seus produtores. Pequenas indústrias da região de Londrina, Paraná, produzem embutidos que são comercializados em feiras livres, pequenos mercados, bares e restaurantes da cidade. Embora essas indústrias sejam fiscalizadas pelo Serviço de Inspeção Municipal de Londrina, não existem dados sobre microrganismos patogênicos presentes nesses produtos. Os objetivos deste estudo foram pesquisar a presença de Salmonella spp. em amostras de linguiças produzidas e comercializadas na região de Londrina, Paraná, e identificar os genes de virulência eae, $b f p$, stx $1, s t x 2$, hlyA, ipaH, elt, est, aggR, aap e AA probe das cepas de E. coli isoladas dessas amostras. Quarenta e seis amostras de três tipos de linguiça (suína fresca, toscana e calabresa) produzidas por quatro diferentes produtores (marcas A, B, C e D) foram analisadas. Salmonella spp. foi isolada em 13 (28.3\%) amostras e E. coli em 33 (71.3\%) amostras. Das 13 amostras contaminadas com Salmonella spp., sete (53.8\%) foram da marca A. A contaminação por Salmonella spp. foi maior nas amostras de linguiça toscana (8/17 - 41.7\%) quando comparada com a contaminação encontrada nas amostras de linguiça suína (4/22 - 18.2\%), independente da marca analisada. E. coli foi isolada de 12 das 13 amostras contaminadas com Salmonella spp. Uma amostra de linguiça calabresa estava contaminada com E. coli enteropatogênica clássica atípica do sorotipo O108:H9, que apresentava genes eae e $h l y A$. Os resultados obtidos sugerem contaminação da planta de processamento e ou das matérias primas utilizadas na fabricação das linguiças. Uma fiscalização mais adequada das indústrias se torna necessária para que as Boas Práticas de Fabricação sejam atendidas e, consequentemente, prevenida a contaminação do produto por bactérias patogênicas.

Palavras-chave: Carne suína. Bactérias enteropatogênicas. Genes de virulência.

\section{Introduction}

The prevention of meat product contamination is a challenge faced by the meat industry. The presence of pathogenic microorganisms in these food products may result in foodborne diseases and economic losses to their producers, such as the need to dispose of the contaminated batch and lawsuits by consumers who become ill due to the ingestion of the contaminated product.

Many studies have reported the isolation of diarrheagenic E. coli and Salmonella spp. in pork meat and its derivates (MÜRMANN et al., 2007; LIMA et al., 2011; CHARIMBA et al., 2012; RANTSIOU et al., 2012; CABRAL et al., 2014). According to the Brazilian Health Ministry, 6,848 outbreaks of foodborne diseases were reported between 2007 and 2016 that resulted in 121,283 cases of illness, 17,517 hospitalizations (14.5\%), and 111 deaths $(0.09 \%)$. The main etiologic agents responsible for the outbreaks were Salmonella spp. (7.3\%), Escherichia coli (7.3\%), and
Staphylococcus aureus (5.7\%). The contaminated food was not identified in majority of the reported outbreaks $(66.9 \%)$. Mixed foods were the main cause of the outbreaks where the contaminated food had been identified $(2,266,33.1 \%)$. Raw pork meat and derivatives and pork offal were responsible for $103(4.5 \%)$ of the reported outbreaks that had known etiology (BRASIL, 2017).

Eight diarrheagenic E. coli (DEC) groups are known: shiga toxin-producing E. coli (STEC), which includes the subgroup enterohemorrhagic $E$. coli (EHEC); typical and atypical enteropathogenic E. coli (EPECt and EPECa); enterotoxigenic E. coli (ETEC); enteroinvasive E. coli (EIEC); enteroaggregative $E$. coli (EAEC); diffusely adherent E. coli (DAEC); and adherent invasive E. coli (AIEC). Enteroaggregative hemorrhagic E. coli (EAHEC) O104:H4 is an emerging E. coli pathotype associated with an outbreak that occurred in Germany in May 2011. The genes used for genetic characterization of these groups are stx 1 
and stx2 (STEC); stx1, stx2, and eae (EHEC); eae (EPECa); eae and $b f p$ (EPECt); enterotoxin genes LT and ST and colonization factors (ETEC); ipaH and ial (EIEC); and $a g g R$, aap, and AA probe (EAEC) (CROXEN et al., 2013). Genes for the genetic characterization of AIEC have not yet been characterized and there is no agreement among authors for the genetic characterization of DAEC (NATARO; KAPER, 1998; CROXEN et al., 2013). EAHEC O104:H4 is an enteroaggregative E. coli with the $s t x 2$ a encoding gene (BEUTIN; MARTIN, 2012).

The incidence of gastroenteritis caused by EAEC and EPEC, specially EPECa, has increased in Brazil (REGUA-MANGIA et al., 2004; FRANZOLIN et al., 2005; MORENO et al., 2010; LOZER et al., 2013; DIAS et al., 2016). In the last few years, EPECa was isolated as the cause of gastroenteritis in Brazil in more cases than EPECt, and as a shiga toxin-producing E. coli (STEC), it is an emerging food pathogen (SCHMIDT, 2010).

EPECa serotypes have already been reported in the feces of pig, and pork meat may be a vehicle of transmission of this bacterium to humans. The infection of pig herds by Salmonella tends to be a persistent problem in food production systems. Submandibular lymph nodes and tonsils of pigs contaminated by Salmonella spp. may remain in the carcasses after slaughter, and combined with head region muscles, be used in processed meat manufacturing.

Brazil is the fourth largest producer and exporter of pork meat. In 2016, Brazil produced about 3.7 million tons and $19.6 \%$ of this was exported. In Brazil, the per capita consumption of pork meat in 2016 was $14.4 \mathrm{~kg}$. Paraná is the second largest producer of pork meat and produced $13.2 \%$ of the total of the pork meat exported by Brazil in 2016. In this year, $13.2 \%$ of swine slaughtered in Brazil was in Paraná (ABPA, 2017).

In Londrina, Paraná, Brazil and the surrounding areas there are some meat processing industries that commercialize their products in free fairs, small markets, bars, and restaurants of the city. The Municipal Inspection Service of Londrina is responsible for the inspection of these industries. However, there are no data about the pathogenic microorganisms present in these products.

The aims of this study were to evaluate the presence of Salmonella spp. in sausage samples produced and commercialized in Londrina, and identify eae, bfp, stx1, stx2, hlyA, ipaH, elt, aggR, $a a p$, and $A A$ probe genes in E. coli strains isolated from the sausage samples.

\section{Material and Methods}

Sampling

Forty-six samples of three types of fresh sausages (22 fresh pork, 17 Tuscan, and 7 Calabresa) produced by four different producers of Londrina, Paraná, Brazil and the surrounding areas were purchased weekly from March to July 2015 in four supermarkets of Londrina. The brands were nominated as A, B, C, and D. The number of samples from brands $\mathrm{C}$ and $\mathrm{D}$ were smaller because these brands were not always available for purchase.

\section{Salmonella spp. detection}

Salmonella spp. detection was performed according to Silva et al. (2017). Twenty-five grams of each sample was homogenized in $225 \mathrm{~mL}$ of buffered peptone water in a Stomacher blender (Stomacher 400, Seward, Worthing, England). After incubation at $35^{\circ} \mathrm{C}$ for $24 \mathrm{~h}, 1.0 \mathrm{~mL}$ and 0.1 $\mathrm{mL}$ aliquots of the non-selective enrichment were inoculated, respectively, in $10 \mathrm{~mL}$ of Selenite Cystine Broth (SC) (Himedia Laboratories Pvt. Ltd., Mumbai, India) and in $10 \mathrm{ml}$ of RappaportVassiliadis (RV) broth (Himedia Laboratories). The SC broth was incubated at $35^{\circ} \mathrm{C}$ and $\mathrm{RV}$ broth at $42^{\circ} \mathrm{C}$ for $24 \mathrm{~h}$. Hektoen agar (Himedia Laboratories) and Xylose Lysine Deoxycholate (XLD) (Himedia Laboratories) used as selective 
and differential media, were incubated at $35^{\circ} \mathrm{C}$ for $24 \mathrm{~h}$. Biochemical screening using motility, production of indole, decarboxylation of lysine, and hydrolysis of urea was carried out with the characteristic colonies of Salmonella spp. The confirmation of Salmonella genus was performed using the agglutination technique with polyvalent antiserum anti-Salmonella spp. according to the manufacturer's recommendation (Probac do Brasil, São Paulo, Brasil).

\section{Isolation of E. coli}

E. coli isolation was carried out using traditional culture media according to Silva et al. (2017). Twenty-five grams of each sample was homogenized in $225 \mathrm{~mL}$ of buffered peptone water in a Stomacher blender (Stomacher 400). Aliquots of $1 \mathrm{~mL}$ were inoculated in tubes containing $10 \mathrm{~mL}$ of sodium lauryl sulfate (SLS) (Himedia Laboratories) and incubated at $35^{\circ} \mathrm{C}$ for $24 \mathrm{~h}$. After incubation, SLS tubes were inoculated in eosin methylene blue (EMB) (Himedia Laboratories) and xylose lysine deoxycholate agar (XLD) (Himedia Laboratories) and incubated at $35^{\circ} \mathrm{C}$ for $24 \mathrm{~h}$. The colonies that were lactose positive and non- $\mathrm{H}_{2} \mathrm{~S}$ producing were submitted to the following biochemical screening: production of indole, lactose fermentation with gas production, and citrate as the sole source of carbon. The E. coli strains were stored in nutrient agar (Himedia Laboratories).

\section{DNA extraction of E. coli strains for use in PCR}

E. coli strains stored in nutrient agar were resuspended in sterile saline solution and cultivated on MacConkey agar (Himedia Laboratories Pvt. Ltd., Mumbai, India). After incubation at $35^{\circ} \mathrm{C}$ for $24 \mathrm{~h}$, colonies were resuspended in $200 \mu \mathrm{L}$ of sterile water, boiled in a water bath for $10 \mathrm{~min}$, and centrifuged at $10,000 \times g$ for $5 \mathrm{~min}$. The supernatant was used as DNA target in the amplification reactions.

Positive and negative controls used in the PCR assays

The diarrheagenic E. coli strains used as positive controls in PCR assays were EHEC ATCC ${ }^{\circledR}$ 43889 ${ }^{\mathrm{TM}}$ (stx2+, eae + , and $\left.h l y A+\right)$, EPEC 2348/69 $\left(e a e^{+}\right.$and $\left.b f p+\right)$, EHEC H30 (stx1+), EIEC O152 $(i p a H+)$, ETEC H10407 (elt+), ETEC B41 (est+), and EAEC O42 (aggR+). E. coli K12, Hb101, and $\mathrm{DH} 5 \alpha$ were used as negative controls.

PCR conditions for the detection of the virulence genes of diarrheagenic E. coli

The virulence genes of diarrheagenic E. coli were detected using the following virulence markers: eae (a gene that encodes intimin present in EPEC and EHEC), $b f p$ (a gene that encodes $b f p$ present in typical EPEC), $\operatorname{agg} R$ (a transcriptional activator for AAFs in EAEC), elt and est (genes that encoded LT and ST toxins in ETEC), ipaH (a gene present in the invasion plasmid that encodes the $\mathrm{H}$ antigen in EIEC), st 1 and st $x 2$ (genes that encode the shiga toxin in STEC), and hlyA (a gene that encodes enterohemolysin in EHEC). The primer sequences and sizes of the amplified DNA are described in Table 1. The conditions used in the PCR assays are presented in Table 2. 
Table 1. Primers used for detection of the virulence genes of diarrheagenic E. coli.

\begin{tabular}{|c|c|c|}
\hline Genes & Primers $\left(5^{\prime}-3^{\prime}\right)$ & PCR product (bp) \\
\hline hly $A^{1}$ & $\begin{array}{l}\text { (F) GCATCATCAAGCGTACGTTCC } \\
\text { (R) AATGAGCCAAGCTGGTTAAGCT }\end{array}$ & 534 \\
\hline$e a e^{I}$ & $\begin{array}{l}\text { (F) GACCCGGCACAAGCATAAGC } \\
\text { (R) CCACCTGCAGCAACAAGAGG }\end{array}$ & 384 \\
\hline$s t x 1^{1}$ & $\begin{array}{l}\text { (F) ATAAATCGCCATTCGTTGACTAC } \\
\text { (R) AGAACGCCCACTGAGATCATC }\end{array}$ & 180 \\
\hline$s t x 2^{1}$ & $\begin{array}{l}\text { (F) GGCACTGTCTGAAACTGCTCC } \\
\text { (R) TCGCCAGTTATCTGACATTCTG }\end{array}$ & 255 \\
\hline$e l t^{2}$ & $\begin{array}{l}\text { (F) GGCGACAGATTATACCGTGC } \\
\text { (R) CGGTCTCTATATTCCCTGTT }\end{array}$ & 190 \\
\hline$i p a H^{2}$ & $\begin{array}{l}\text { (F) TTCCTTGACCGCCTTTCCGATACCGTC } \\
\text { (R) GCCGGTCAGCCACCCTCTGAGAGTAC }\end{array}$ & 600 \\
\hline$b f p^{2}$ & $\begin{array}{l}\text { (F) AATGGTGCTTGCGCTTGCTGC } \\
\text { (R) GCCGCTTTATCCAACCTGGTA }\end{array}$ & 326 \\
\hline$a a p^{3}$ & $\begin{array}{l}\text { (F) CTTGGGTATCAGCCTGAATG } \\
\text { (R) AACCCATTCGGTTAGAGCAC }\end{array}$ & 310 \\
\hline $\operatorname{agg} R^{3}$ & $\begin{array}{l}\text { (F) CTAATTGTACAATCGATGTA } \\
\text { (R) AGAGTCCATCTCTTTGATAAG }\end{array}$ & 457 \\
\hline AA probe ${ }^{3}$ & $\begin{array}{l}\text { (F) CTGGCGAAAGACTGTATCAT } \\
\text { (R) CAATGTATAGAAATCCGCTGTT }\end{array}$ & 629 \\
\hline
\end{tabular}

${ }^{1}$ Paton \& Paton, 1998; ${ }^{2}$ Aranda et al., 2004; ${ }^{3}$ Cerna, Nataro \& Estrada-Garcia, 2003.

Table 2. The amplification conditions used in the PCR assay for the detection of eae, bfp, stx1, stx2, hlyA, ipaH, elt, aggR, aap, and $A A$ probe genes of $E$. coli isolated from sausage samples.

\begin{tabular}{ll}
\hline Genes & PCR reaction mixture* \\
\hline & $2.5 \mu \mathrm{L}$ of DNA template in a total reaction \\
eae, st $x 1$, & volume of $25.0 \mu \mathrm{L}$ containing $1.5 \mathrm{U}$ of $T a q$ \\
stx 2, and & DNA polymerase, $0.4 \mathrm{mM}$ of $\mathrm{dNTPs}, 2.5$ \\
$h l y \mathrm{~A}$ & $\mathrm{mM}$ of $\mathrm{MgCl}_{2}, 20.0 \mathrm{pmol} / \mathrm{L}$ of each primer, \\
& $2.5 \mu \mathrm{L}$ of PCR buffer $10 \mathrm{x}^{* *}$
\end{tabular}

$2.5 \mu \mathrm{L}$ of DNA template in a total reaction ipaH, volume of $25.0 \mu \mathrm{L}$ containing $1.0 \mathrm{U}$ of $\mathrm{Taq}$ est, and DNA polymerase, $0.4 \mathrm{mM}$ of dNTPs, 2.5 elt $\quad \mathrm{mM}$ of $\mathrm{MgCl}_{2}, 20.0 \mathrm{pmol} / \mathrm{L}$ of each primer, $2.5 \mu \mathrm{L}$ of PCR buffer $10 \mathrm{x}^{* *}$

$2.5 \mu \mathrm{L}$ of DNA template in a total reaction aap, $\quad$ volume of $20.0 \mu \mathrm{L}$ containing $1.0 \mathrm{U}$ of Taq $\operatorname{agg} R$, and $A A$ probe DNA polymerase, $0.4 \mathrm{mM}$ of dNTPs, 2.5 $\mathrm{mM}$ of $\mathrm{MgCl}_{2}, 10.0 \mathrm{pmol} / \mathrm{L}$ of aap primer, $15.0 \mathrm{pmol} / \mathrm{L}$ of $\operatorname{aggR}$ primer, and $20.0 \mathrm{pmol} / \mathrm{L}$ AA probe primer, $2.5 \mu \mathrm{L}$ of PCR buffer $10 \mathrm{x}^{* *}$
Amplification conditions References

Initial denaturation at $95^{\circ} \mathrm{C}$ for $5 \mathrm{~min}$; 15 cycles of $95^{\circ} \mathrm{C}$ for $1 \mathrm{~min}, 2 \mathrm{~min}$ at $65^{\circ} \mathrm{C}, 1.5 \mathrm{~min}$ at $72^{\circ} \mathrm{C} ; 20$ cycles of $94^{\circ} \mathrm{C}$ for $1 \mathrm{~min}, 2 \mathrm{~min}$ at $60^{\circ} \mathrm{C}, 2.5$ min at $72^{\circ} \mathrm{C}$; and a final extension at $72^{\circ} \mathrm{C}$ for $7 \mathrm{~min}$.

Initial denaturation at $95^{\circ} \mathrm{C}$ for 5 min, followed by 40 cycles of $95^{\circ} \mathrm{C}$ for $1 \mathrm{~min}, 2 \mathrm{~min}$ at $54^{\circ} \mathrm{C}, 1.0 \mathrm{~min}$ at $72^{\circ} \mathrm{C}$; and a final extension at $72^{\circ} \mathrm{C}$ for $7 \mathrm{~min}$.

Initial cycle at $50^{\circ} \mathrm{C}$ for $2 \mathrm{~min}$, denaturation at $95^{\circ} \mathrm{C}$ for $3 \mathrm{~min}$, followed by 40 cycles of $95^{\circ} \mathrm{C}$ for 40 s, $40 \mathrm{~s}$ at $59^{\circ} \mathrm{C}, 40 \mathrm{~s}$ at $72^{\circ} \mathrm{C}$; and a final extension at $72^{\circ} \mathrm{C}$ for $7 \mathrm{~min}$.
Paton \& Paton (1988), with some modification

Aranda (2004), with some modification

Cerna, Nataro \& EstradaGarcia (2003), with some modification 
continuation

$2.5 \mu \mathrm{L}$ of DNA template in a total reaction volume of $25.0 \mu \mathrm{L}$ containing $1.0 \mathrm{U}$ of $\mathrm{Taq}$ bfp DNA polymerase, $0.4 \mathrm{mM}$ of dNTPs, 2.5 $\mathrm{mM}$ of $\mathrm{MgCl}_{2}, 20.0 \mathrm{pmol} / \mathrm{L}$ of $b p f$ primer, 2.5 $\mu \mathrm{L}$ of PCR buffer $10 \mathrm{x} * *$
Initial cycle at $50^{\circ} \mathrm{C}$ for $2 \mathrm{~min}$, denaturation at $95^{\circ} \mathrm{C}$ for $3 \mathrm{~min}$, followed by 40 cycles of $95^{\circ} \mathrm{C}$ for 40 $\mathrm{s}, 40 \mathrm{~s}$ at $59^{\circ} \mathrm{C}, 40 \mathrm{~s}$ at $72^{\circ} \mathrm{C}$; and a final extension at $72^{\circ} \mathrm{C}$ for $7 \mathrm{~min}$.
Aranda

(2004),

with some modification

* Invitrogen Life Technologies, Alameda, CA, EUA

** 20 mM Tris- $\mathrm{HCl}, 50$ mM KCl, pH 8.4.

All amplification reactions were performed in Veriti $^{\circledR}$ thermocycler (Applied Biosystems ${ }^{\circledR}$, Foster City, CA, USA). Aliquots of $10 \mu \mathrm{L}$ of each reaction were homogenized with $1 \mu \mathrm{L} 20 \mathrm{x}$ Red Gel (Biotium ${ }^{\circledR}$, Hayward, CA, USA). The electrophoresis was carried out on $2 \%$ agarose in 1x Tris-Borate-EDTA buffer [Tris $\left(\right.$ Invitrogen $^{\circledR}$ ) 90 mM; boric acid (Nuclear, Diadema, São Paulo) $90 \mathrm{mM}$, EDTA (Nuclear) $2 \mathrm{mM}$ ] at $70 \mathrm{~V}$ for 100 min. A DNA fragment of $1 \mathrm{~Kb}$ (Invitrogen ${ }^{\circledR}$ ) was used as molecular size marker. Gels were viewed under ultraviolet light (UV) (Loccus Biotecnologia Molecular, Cotia, São Paulo, Brasil) and photodocumented (L-Pix Image Versão 1.21, Loccus Biotecnologia Molecular). Samples showing bands corresponding to the hlyA gene in the multiplex PCR were confirmed by uniplex PCR using only the hlyA primers.

Serotyping of diarrheagenic E. coli

After detection of the virulence genes of diarrheagenic E. coli by PCR, one of the E. coli strains that harbored the eae and hlyA genes was serotyped at the Health Public Department, Medicine Faculty, National University of Mexico, Mexico City.

\section{Results and Discussion}

Salmonella spp. were isolated in 13 (28.3\%) and E. coli in $33(71.3 \%)$ of the 46 pork sausage samples analyzed in this study. The contamination by Salmonella spp. was higher in Tuscan sausage samples $(8 / 17,41.7 \%)$ than in fresh pork sausage samples $(4 / 22,18.2 \%)$. E. coli were isolated in 12 of 13 samples positive for Salmonella spp. (Table 3). Seven (53.8\%) of 13 samples contaminated with Salmonella spp. were from brand A. Additionally, five from the eight samples of Tuscan sausages positive for Salmonella spp. (62.5\%) were also from this brand. All samples of fresh pork and Tuscan sausage from brand A were contaminated by E. coli. A high percentage of contamination by $E$. coli also was found in fresh pork and Tuscan sausages from brand B $(12 / 15,80.0 \%)$. 
Table 3. Results of the detection of Salmonella spp. and E. coli in samples of Calabresa, fresh pork, and Tuscan sausages analyzed.

\begin{tabular}{|c|c|c|c|c|}
\hline $\begin{array}{c}\text { Producer } \\
\text { (No. samples analyzed) }\end{array}$ & Type of sausage & $\begin{array}{c}\text { No. of } \\
\text { samples }\end{array}$ & $\begin{array}{c}\text { Samples } \\
\text { contaminated with } \\
\text { E. coli }\end{array}$ & $\begin{array}{l}\text { Samples contaminated } \\
\text { with Salmonella }\end{array}$ \\
\hline $\begin{array}{c}\mathrm{A} \\
(\mathrm{n}=18)\end{array}$ & $\begin{array}{l}\text { Calabresa } \\
\text { Fresh pork } \\
\text { Tuscan }\end{array}$ & $\begin{array}{l}2 \\
9 \\
7\end{array}$ & $\begin{array}{l}0 \\
9 \\
7\end{array}$ & $\begin{array}{l}0 \\
2 \\
5\end{array}$ \\
\hline $\begin{array}{c}\mathrm{B} \\
(\mathrm{n}=18)\end{array}$ & $\begin{array}{l}\text { Calabresa } \\
\text { Fresh pork } \\
\text { Tuscan }\end{array}$ & $\begin{array}{c}3 \\
10 \\
5\end{array}$ & $\begin{array}{c}0 \\
10 \\
2\end{array}$ & $\begin{array}{l}0 \\
2 \\
1\end{array}$ \\
\hline $\begin{array}{c}\mathrm{C} \\
(\mathrm{n}=5)\end{array}$ & $\begin{array}{l}\text { Calabresa } \\
\text { Fresh pork } \\
\text { Tuscan }\end{array}$ & $\begin{array}{l}0 \\
2 \\
3\end{array}$ & $\begin{array}{l}0 \\
1 \\
1\end{array}$ & $\begin{array}{l}0 \\
0 \\
1\end{array}$ \\
\hline $\begin{array}{c}\mathrm{D} \\
(\mathrm{n}=5)\end{array}$ & $\begin{array}{l}\text { Calabresa } \\
\text { Fresh pork } \\
\text { Tuscan }\end{array}$ & $\begin{array}{l}2 \\
1 \\
2\end{array}$ & $\begin{array}{l}1^{a} \\
1 \\
1\end{array}$ & $\begin{array}{l}1 \\
0 \\
1\end{array}$ \\
\hline
\end{tabular}

${ }^{a}$ Sample contaminated with EPECa O108:H9 that harbored the genes eae and hlyA.

The number of samples from brands $\mathrm{C}(\mathrm{n}=5)$ and $D(n=5)$ were smaller than those from brands A $(n=18)$ and B $(n=18)$. However, E. coli and Salmonella were also isolated in samples from these two brands. Two out of seven samples of Calabresa sausage from brand $\mathrm{D}$ were contaminated with Salmonella spp. One of the samples was also contaminated with E. coli serotype O108:H9 that harbored the genes eae and hlyA.

Other studies conducted in the South of Brazil have reported percentages of isolation of Salmonella spp. in sausages similar to that found in this work (13/46, 28.3\%). Mürmann et al. (2009) and Souza et al. (2014) detected Salmonella spp. in $24.4 \%(84 / 336)$ and $30.0 \%(6 / 20)$ of the fresh sausage samples analyzed in Porto Alegre, RS and in Cascavel, PR, respectively. In Niteroi, Rio de Janeiro, the percentage of fresh sausages contaminated with Salmonella spp. was higher than that found in the present study and ranged from $37.0 \%(10 / 27)$ to $53.0 \%(58 / 91)$ (LIMA et al., 2011; CABRAL, et al., 2014). However, in other studies conducted in Brazil, the contamination of pork meat and its derivatives was much lower, with percentages ranging from 5.0 to $17.9 \%$ (CHAVES et al., 2000; LOBO et al., 2001; SPRICIGO et al., 2008a; BEZERRA et al., 2012).

The prevalence of Salmonella spp. in the brand B samples may be related to the contamination of the pork meat or other ingredients used in the production of some batches. Two fresh pork and one Tuscan sausage sample was collected at an interval of four months. Salmonella spp. was not isolated from samples collected in the intermediate period. However, it should be noted that E. coli was isolated in $12(80.0 \%)$ of the 15 -fresh pork and Tuscan sausage samples of this brand, which indicated inadequate hygienic-sanitary conditions 
of processing, or the contamination of raw pork meat.

Lima et al. (2011) in Niterói, Rio de Janeiro analyzed the surface of sausages using swabs and subsequently the meat from these same samples. The meat of $33.0 \%$ of the samples was contaminated with Salmonella spp. while contamination was only present on the surface in $11.0 \%$ of the samples. These results indicated that the contamination probably occurred due to the use of pork raw meat contaminated with Salmonella. In another study conducted by Cabral et al. (2014), there was no statistical difference in the Salmonella contamination of sausages analyzed in their original packaging compared to those repackaged by the market itself or sold in bulk to the consumer. These authors have suggested that food handling and storage in retail outlets appear to play a minor role in the contamination of sausages and that the main cause of contamination of the product is the contaminated raw pork meat used in the manufacture of sausages.

Infection of swine herds by Salmonella spp. tends to be a persistent problem in production systems. Castagna et al. (2004b) reported a high percentage of pigs carrying Salmonella spp. in submandibular lymph nodes and tonsils, which may remain in the carcass after slaughter. These parts can be used along with the head muscles in the manufacture of sausages and mechanically separated meat. These ingredients, when contaminated, may be responsible for the presence of Salmonella in those products. The removal of the tonsils from carcass after slaughter does not eliminate the risk of contamination, but it can be reduced in about $30.0 \%$. The removal of the submandibular lymph nodes during processing is difficult because they are firmly attached to the musculature of the head (CASTAGNA et al., 2004a).

It is almost impossible to avoid crosscontamination of carcasses during the slaughter of swine. The use of only Good Manufacturing Practices in the slaughter process does not seem to be effective in reducing the meat contamination by Salmonella spp. More effective measures are related to the production of Salmonella spp. free swine and decontamination of the carcasses (BERENDS, 1998).

The percentage of contamination, $12.6 \%$, found in pork meat samples produced in Portugal is much higher than the percentage reported in the European Union $(0.7 \%)$. This difference in contamination can be explained by the fact that Portugal does not have a national program for the control of Salmonella in primary production, although it has a monitoring system for the contamination of pork carcasses after slaughter. Control strategies should be implemented on farms to reduce carcass contamination because cross-contamination during slaughter is the most common form of contamination of pork meat and its derivatives (XAVIER et al., 2014).

The highest frequency of Salmonella isolation in the present study was in the Tuscan sausage samples from brand A (71.4\%). Samples were collected weekly over a period of three months, suggesting possible contamination of the processing plant and not contamination of a single batch of the product. Two of the nine fresh pork sausage samples from the same brand were also positive for Salmonella.

Alban et al. (2002) reported contamination of $<50$ to $400 \mathrm{CFU}$ of Salmonella spp. $/ \mathrm{cm}^{2}$ on the surface of the swine carcass, with a reduction of 2.0 to $3.0 \mathrm{log}$ during the sausage manufacture. Mataragas et al. (2015) found that Salmonella enterica contamination can be reduced by $1.0 \log$ or more during the sausage making process, in which changes in $\mathrm{pH}$ and water activity occur. Inhibition of multiplication occurs at $\mathrm{pH}$ values below 5.3 and therefore, the time and temperature at which raw meat remains at a $\mathrm{pH}$ above 5.3 are critical (LUCKE, 2000; ICMSF, 2005).

Although the reduction of contamination during sausage production may occur in Brazil, Mürmann et al. (2007) reported a count ranging from 0.03 
NMP g-1 to $460 \mathrm{NMP} \mathrm{g}^{-1}$ and Spricigo et al. (2008b) found counts ranging from $<3 \mathrm{NMP}^{-1}$ to 1100 NMP g-1 in the 54 positive samples analyzed. The Brazilian legislation defines that Salmonella spp. must be absent in $25 \mathrm{~g}$ of the analyzed sample (BRASIL, 2001).

None of the E. coli isolates analyzed in this study presented virulence genes used in the genetic characterization of enteroaggregative $E$. coli (EAEC), enterotoxigenic E. coli (ETEC), enteroinvasive $E$. coli (EIE), or shiga toxinproducing E. coli (STEC). A DEC strain was detected in a Calabresa sausage sample from brand D. This isolate harbored the genes eae and hlyA and was identified as EPECa O108: H9. The O108 serogroup was already associated with an outbreak of human gastroenteritis in the city of Mairiporã, SP, Brazil (VIEIRA et al., 2016) and the serotype O108: H9 has already been isolated from swine feces (FROHLICHER el al., 2008; MALIK et al., 2006). Although there is no evidence of transmission from animals to humans, it is believed that some isolates of EPECa could be zoonotic pathogens (GOMES et al., 2016).

The prevalence of infections caused by EPEC varies considerably according to age, socioeconomic status, and geographic region of the populations studied. EPECt isolates have always been strongly associated with childhood diarrhea; however, recent studies have shown a higher frequency of EPECa as a cause of diarrhea in Brazil and other South American countries (GOMES et al., 2004; ARAUJO et al., 2007; OCHOA et al., 2009; HANNAOUI et al., 2010; LOZER et al., 2013; RUGÉLES et al., 2010; SCHMIDT, 2010; ASSIS et al., 2014; GOMES et al., 2016).

Isolates of EPEC are classified as typical when they have the adhesion factor plasmid (EAF) and the $b f p$ gene, in addition to the eae gene. The serogroups of EPECa differ from those of EPECt, indicating that few EPECa isolates are EPEC isolates that have lost the EAF plasmid (SCHMIDT, 2010). Unlike EPECt, many EPECa isolates are found in several sick or healthy animal species. Recently, Borges et al. (2017) isolated EPEC (typical and atypical) and STEC in wild birds and feral pigeons in the city of São Paulo.

E. coli O108: H9 strain isolated in this study from Calabresa sausage did not present the stx gene. Enterohemorrhagic E. coli (EHEC) is a subtype of STEC that encodes, besides the stx gene, hlyA and eae genes. The eae gene is responsible for the attaching and effacing (AE) lesion (CROXEN et al., 2013). According to Bielaszewska et al. (2007), EHEC isolates may lose stx genes during infection, isolation, or subculture. We do not believe that the serotype O108: H9 isolated in this study had lost the stx gene because it is not one of the classic serotypes of shiga toxin-producing E. coli (O157:H7, O26, O45, O103, O111, O121, and O145) (CROXEN et al., 2013).

Some brands of Calabresa sausages are subject to a cooking process during their production, allowing their consumption without previous cooking. Tuscan and pork sausages, however, are raw and prepared in barbecue or oven grills, baked in conventional ovens, or deep fried. Therefore, the risk for human health that this product may present is more related to the cross contamination to other foods, especially those ingested raw, or the ingestion of the sausage after inadequate thermal process (ESCARTIN et al., 2000; GORMAN et al., 2002).

The standardization and control of all stages of the sausage process are crucial to obtain a product free of contamination. Excessive handling, inappropriate sanitation of instruments and equipment, the absence or deficiency of Good Manufacturing Practices and Hazard Analysis Critical Control Points (HACCP) system affect the sanitary quality of this type of food. In addition, the lack of proper preparation instructions can lead to cross-contamination and consumption of contaminated products. 


\section{Conclusion}

Salmonella spp. and E. coli were isolated in $28.3 \%$ and $71.3 \%$ of the analyzed samples, respectively. A sample of Calabresa sausage was contaminated with atypical enteropathogenic $E$. coli from serotype O108: H9, which harbored the eae and hlyA genes. The results suggest possible contamination of the processing plant and/or raw meat used in the manufacture of sausages. A better inspection of the industries is required to ensure that good manufacturing practices are followed and thus the contamination of the product by pathogenic bacteria be prevented.

\section{Acknowledgment}

The authors express their gratitude to the CAPES (Coordenação de Aperfeiçoamento de Pessoal de Nível Superior) for the Master's scholarship of Paola Bianca Barbosa Cavalin and to the CNPq (Conselho Nacional de Desenvolvimento Científico e Tecnológico) for the financial support. The serotyping of $E$. coli was performed with the financial support of the Dirección General de Asuntos del Personal Académico (DGAPA), Programa de Apoyo a Proyectos de Investigación e Innovación Tecnológica (PAPIIT), project IN216417, UNAM, Mexico.

\section{References}

ALBAN, L.; OLSEN, A. M.; NIELSEN, B.; SORENSEN, R.; JESSEN, B. Qualitative and quantitative risk assessment for human salmonellosis due to multi-resistant Salmonella Typhimurium DT 104 from consumption of Danish dry-cured pork sausages. Preventive Veterinary Medicine, Amsterdam, v. 52, n. 3-4, p. 251-265, 2002.

ASSIS, F. E. A.; WOLF, S.; SUREK, M.; DE TONI, F.; SOUZA, E. M.; PEDROSA, F. O.; FARAH, S. M. S. S.; PICHETH, G.; FADEL-PICHETH, C. M. T. Impact of Aeromonas and diarrheagenic Escherichia coli screening in patients with diarrhea in Paraná, Southern Brazil. The Journal of Infection in Developing Countries, Sassari, v. 8, n. 12, p. 1609-1614, 2014.
ARAUJO, J. M.; TABARELLI, G. F.; ARANDA, K. R. S.; FABBRICOTTI, U. F.; MENDES, C. M. F.; SCALETSKY, I. C. A. Typical enteroaggregative and atypical enteropathogenic types of Escherichia coli are the most prevalent diarrhea-associated pathotypes among Brazilian children. Journal of Clinical Microbiology, Washington, v. 45, n. 10, p. 3396-3399, 2007.

ARANDA, K. R.; FAGUNDES-NETO, U.; SCALETSKY, I. C. Evaluation of multiplex PCRs for diagnosis of infection with diarrheagenic Escherichia coli and Shigella spp. Journal of Clinical Microbiology, Washington, v. 42, n. 1, p. 5849-5853, 2004.

ASSOCIAÇÃO BRASILEIRA DE PROTEÍNA ANIMAL - ABPA. Relatório Anual ABPA 2016. Disponível em: $\quad<$ http://abpa-br.com.br/setores/ avicultura/publicacoes/relatorios-anuais $>$. Acesso em: 27 out. 2017.

BERENDS, B. R.; VAN KNAPEN, F.; MOSSEL, D. A. A.; BURT, S. A.; SNIJDERS, J. M. A. Impact on human health of Salmonella spp. on pork in The Netherlands and the anticipated effects of some currently proposed control strategies. International Journal of Food Microbiology, Amsterdam, v. 44, n. 3, p. 219-229, 1998.

BEUTIN, L.; MARTIN, A. Outbreak of Shiga ToxinProducing Escherichia coli (STEC) O104:H4 infection in Germany causes a paradigm shift with regard to human pathogenicity of STEC strains. Journal of Food Protection, Des Moines, v. 75, n. 2, p. 408-418, 2012.

BEZERRA, M. V. P.; ABRANTES, M. R.; SILVESTRE, M. K. S.; SOUSA, E. S.; ROCHA, M. O. C.; FAUSTINO, J. G.; SILVA, J. B. A. Avaliação microbiológica e físicoquímica de linguiça toscana no Município de Mossoró, RN. Arquivos do Instituto Biológico, São Paulo, v. 79, n. 2, p. 297-300, 2012.

BIELASZEWSKA，M; PRAGER，R.; KÖCK，R.; MELLMANN, A.; ZHANG, W.; TSCHÄPE, H.; TARR, P. I.; KARCH, H. Shiga toxin gene loss and transfer in vitro and in vivo during enterohemorrhagic Escherichia coli $\mathrm{O} 26$ infection in humans. Applied and Environmental Microbiology, Washington, v. 73, n. 10, p. 3144-3150, 2007.

BORGES, C. A.; CARDOZO, M. V.; BERALDO, L. G.; OLIVEIRA, E. S.; MALUTA, R. P.; BARBOZA, K. B.; WERTHER, K.; ÁVILA, F. A. Wild birds and urban pigeons as reservoirs for diahrreagenic Escherichia coli with zoonotic potential. Journal of Microbiology, Seoul, v. 55, n. 5. p. 344-348. 2017.

BRASIL. Ministério da Saúde. Agência Nacional de Vigilância Sanitária. Resolução RDC $\mathrm{n}^{\circ} 12$, de 02 de janeiro de 2001. Aprova o regulamento técnico sobre 
padrões microbiológicos para alimentos. Diário Oficial [da] República Federativa do Brasil, Brasília, 10 jan. 2001. Seção 1, p. 45-53.

Ministério da Saúde. Secretaria de Vigilância em Saúde. Surtos de doenças transmitidas por alimentos no Brasil. [S.1.: s.n.], dez. 2016. Disponível em: $<$ http://portalarquivos.saude.gov.br/ images/pdf/2016/ dezembro/09/Apresentacao-Surtos-DTA-2016.pdf $>$. Acesso em: 10 jan. 2017.

CABRAL, C. C.; CONTE-JUNIOR, C. A.; SILVA, J. T.; PASCHOALIN, V. M. F. Salmonella spp. contamination in fresh pork and chicken sausages marketed in Niterói and Rio de Janeiro, Brazil. Journal fur Verbraucherschutz und Lebensmittelsicherheit, Heidelberg, v. 9, n. 3, p. 243249, 2014.

CASTAGNA, S. M. F.; SCHWARZ, P.; CANAL, C. W.; CARDOSO, M. Presença de Salmonella sp. no trato intestinal e em tonsilas/linfonodos submandibulares de suínos ao abate. Arquivo Brasileiro de Medicina Veterinária e Zootecnia, Belo Horizonte, v. 56, n. 3, p. 300-306, 2004b.

CASTAGNA, S. M. F.; SCHWARZ, P.; CANAL, C. W.; CARDOSO, M. R. I. Prevalência de suínos portadores de Salmonella sp. ao abate e contaminação de embutidos tipo frescal. Acta Scientiae Veterinariae, Porto Alegre, v. 32, n. 2, p. 141-147, 2004a.

CERNA, J. F.;NATARO, J. P.; ESTRADA-GARCIA, T. Multiplex PCR for detection of three plasmid-borne genes of enteroaggregative Escherichia coli strains. Journal of Clinical Microbiology, Washington, v. 41, n. 5, p. 2138-2140, 2003.

CHARIMBA, G.; HUGO, C.; HUGO, A. The incidence of diarrhoeagenic Escherichia coli in minced beef and boerewors. Food Research International, Essex, v. 47, n. 2, p. 353-358, 2012.

CHAVES, G. M. C.; GONÇALVES, P. M. R.; FRANCO, R. M.; CARVALHO, J. C. A. P. Avaliação bacteriológica de lingüiça frescal suína comercializada no Município do Rio de Janeiro, RJ. Higiene Alimentar, São Paulo, v. 14, n. 13, p. $48-52,2000$.

CROXEN, M.; LAW, R.; SCHOLZ, R.; KEENEY, K.; WLODARSKA, M.; FINLAY, B. Recent advances in understanding enteric pathogenic Escherichia coli. Clinical Microbiology Reviews, Washington, v. 26, n. 4, p. 823-880, 2013.

DIAS, R. C.; DOS SANTOS, B. C.; DOS SANTOS, L. F.; VIEIRA, M. A.; YAMATOGI, R. S.; MONDELLI, A. L.; SADATSUNE, T.; SFORCIN, J.M.; GOMES, T. A.; HERNANDES, R. T. Diarrheagenic Escherichia coli pathotypes investigation revealed atypical enteropathogenic E.coli as putative emerging diarrheal agents in children living in Botucatu, São Paulo State, Brazil. APMIS: Acta Pathologica, Microbiologia, et Immunologica Scandinavica, Copenhagen, v. 124, n. 4, p. 299-308, 2016.

ESCARTIN, E. F.; LOZANO, J. S.; GARCIA, O. R. Quantitative survival of native Salmonella serovars during storage of frozen raw pork. International Journal of Food Microbiology, Amsterdan, v. 54, n. 1-2, p. 19-25. 2000.

FRANZOLIN, M. R.; ALVES, R. C.; KELLER, R.; GOMES, T. A.; BEUTIN, L.; BARRETO, M. L.; MILROY, C.; STRINA, A.; RIBEIRO, H.; TRABULSI, L. R. Prevalence of diarrheagenic Escherichia coli in children with diarrhea in Salvador, Bahia, Brazil. Memórias do Instituto Oswaldo Cruz, Rio de Janeiro, v. 100, n. 4, p. 359-363, 2005.

FROHLICHER, E.; KRAUSE, G.; ZWEIFEL，C.; BEUTIN, L.; STEPHAN, R. Characterization of attaching and effacing Escherichia coli (AEEC) isolated from pigs and sheep. BMC Microbiology, London, v. 8, n. 144, p.144, 2008.

GOMES, T. A. T.; ELIAS, W. P.; SCALETSKY, I. C. A.; GUTH, B. E. C.; RODRIGUES, J. F.; PIAZZA, R. M. F.; FERREIRA, L. C. S.; MARTINEZ, B. M. Diahrreagenic Escherichia coli. Brazilian Journal of Microbiology, São Paulo, v. 47, p. 3-30, 2016. Supplement 1.

GOMES, T.; IRINO, K.; GIRÃO, D. M.; GIRÃO, V. B. C.; GUTH, B. E. C.; VAZ, T. M. I.; MOREIRA, F. C.; CHINARELLI, S. H.; VIEIRA, M. A. M. Emerging enteropathogenic Escherichia coli strains? Emerging Infectious Diseases, Atlanta, v. 10, p. 1851-1855, 2004.

GORMAN, R.; BLOMFIELD, S.; ADLEY, C. A study of cross-contamination of food-borne pathogens in the domestic kitchen in the Republic of Ireland. International Journal of Food Microbiology. Amsterdan, v. 76, n. 1-2, p. 143-150. 2002.

HANNAOUI, E.; VILLALOBOS, L.; MARTÍNEZ, R.; MALDONADO, A.; BASTARDO, J.; HAGEL, I. Diarrheagenic Escherichia coli associated with acute diarrhea in children of Cumaná, Venezuela. Investigacion Clinica, Maracaibo, v. 51, n. 4, p. 489-500, 2010.

INTERNATIONAL COMMISSION ON MICROBIOLOGICAL SPECIFICATIONS FOR FOODS - ICMSF. Microorganisms in Foods 6. Microbial Ecology of Food Commodities. 2. ed. New York: Kluwer Academic, 2005. (Chapter 1).

LIMA, B. R. C. C.; CANTO, A. C. V. C. S.; NASCIMENTO, R. S.; FRANCO, R. M.; NASCIMENTO, E. R. Prevalência de Salmonella spp. 
na superfície e no interior de linguiça frescal suína comercializada no município de Niterói, Rio de Janeiro, Brasil. Revista Brasileira de Medicina Veterinária, São Paulo, v. 33, n. 3, p. 133-136, 2011.

LOBO, M. V.; UGALDE, M. G.; FRIES, L. L. M.; KUBOTA, E. H. Avaliação microbiológica de salames coloniais comercializados no Município de Santa Maria - RS. Higiene Alimentar, São Paulo, v. 15, n. 88, p. 5761, 2001.

LOZER, D.; SOUZA, T. B.; MONFARDINI, M. V.; VICENTINI, F.; KITAGAWA, S. S.; SCALETSKY, I. C.; SPANO, L. C. Genotypic and phenotypic analysis of diarrheagenic Escherichia coli strains isolated from brazilian children living in low socioeconomic level communities. BMC Infectious Diseases, London, v. 13, n. 1, p. 1471-2334, 2013.

LÜCKE, F. Utilization of microbes to process and preserve meat. Meat Science, Amsterdam, v. 56, n. 2, p. 105-115, 2000.

MALIK, A.; TÓTH, I.; BEUTIN, L.; SCHMIDT, H.; TAMINIAU, B.; DOW, M. A.; MORABITO, S.; OSWALD, E.; MAINIL, J.; NAGY, B. Serotypes and intimin types of intestinal and faecal strains of eae + Escherichia coli from weaned pigs. Veterinary Microbiology, Amsterdan, v. 114, n. 1, p.82-93, 2006.

MATARAGAS, M.; BELLIO, A.; ROVETTO, F.; ASTEGIANO, S.; DECASTELLI, L.; COCOLIN, L. Risk-based control of food-borne pathogens Listeria monocytogenes and Salmonella enterica in the Italian fermented sausages Cacciatore and Felino. Meat Science, Amsterdam, v. 103, n. 5, p. 39-45, 2015.

MORENO, A. C.; FILHO, A. F.; GOMES, A.; RAMOS, S. T.; MONTEMOR, L. P.; TAVARES, V. C.; FILHO, S.; IRINO, K.; MARTINEZ, M. B. Etiology of childhood diarrhea in the northeast of Brazil: significant emergent diarrheal pathogens. Diagnostic Microbiology and Infectious Disease, New York, v. 66, n. 1, p. 50-57, 2010.

MÜRMANN, L; SANTOS, M. C. M.; CARDOSO, M. Curvas de crescimento e destruição termica de serovares de Salmonella spp. isolados de linguiça frescal de carne suína. Acta Scientiae Veterinariae, Porto Alegre, v. 37, n. 4, p. 329-335, 2007.

MÜRMANN, M. C. S. Prevalence, genetic characterization and antimicrobial resistance of Salmonella isolated from fresh pork sausages in Porto Alegre, Brazil. Food Control, Vurrey, v. 20, n. 3, p. 191195, 2009.

NATARO, J. P.; KAPER, J. B. Diarrheogenic Escherichia coli. Clinical Microbiology Review, Washington, v. 11, n. 1, p. 142-201, 1998.
OCHOA, T. J.; RUIZ, J.; MOLINA, M.; DEL VALLE, L. J.; VARGAS, M.; GIL, A. I.; ECKER, L.; BARLETTA, F.; HALL, E.; CLEARY, T.G.; LANATA, C.F. High frequency of antimicrobial drug resistante of diarrheagenic Escherichia coli in infants in Peru. The American Journal of Tropical Medicine and Hygiene, Cleveland, v. 81, n. 2, p. 296-301, 2009.

PATON, A. W.; PATON, J. C. Detection and Characterization of Shiga Toxigenic Escherichia coli by Using Multiplex PCR Assays for stx 1 , stx2, eaeA, Enterohemorrhagic E. coli hlyA, rfbO111, andrfbO157. Journal of Clinical Microbiology, Washington, v. 36, n. 2, p. 598-602, 1998.

RANTSIOU, K.; ALESSANDRIA, V.; COCOLIN, L. Prevalence of Shiga toxin-producing Escherichia coli in food products of animal origin as determined by molecular methods. International Journal of Food Microbiology, Amsterdam, v. 154, n. 1-2, p. 37-43, 2012.

REGUA-MANGIA, A. H.; GOMES, T. A.; VIEIRA, M. A.; ANDRADE, J. R.; IRINO, K.; TEIXEIRA, L. M. Frequency and characteristics of diarrhoeagenic Escherichia coli strains isolated from children with and without diarrhea in Rio de Janeiro. Journal of Infection, London, v. 48, n. 2, p. 161-167, 2004.

RÚGELES, L. C.; BAI, J.; MARTÍNEZ, A. J.; VANEGAS, M. C.; GÓMEZ-DUARTE, O. G. Molecular characterization of diarrheagenic Escherichia coli strains from stools samples and food products in Colombia. The Journal of Infection in Developing Countries, Sassari, v. 8, n. 12, p. 1609-1614, 2010.

SCHMIDT, M. A. LEEways: tales of EPEC, ATEC and EHEC. Cellular Microbiology, Oxford, v. 12, n. 11, p. 1544-1552, 2010.

SILVA, N.; JUNQUEIRA, V. C. A.; SILVEIRA, N. F. A.; TANIWAKI, M. H.; GOMES, R. A. R.; OKAZAKI, M. M. Manual de métodos de análise microbiológica de alimentos e água. 5. ed. São Paulo: Editora Edgard Blucher Ltda., 2017.

SOUZA, M.; PINTO, F. G. S.; BONA, E.A. M.; MOURA, A. C. Qualidade higiênico-sanitária e prevalência de sorovares de Salmonella em linguiças frescais produzidas artesanalmente e inspecionadas, comercializadas no oeste do Paraná, Brasil. Arquivos do Instituto Biológico, São Paulo, v. 81, n. 2, p. 107-112, 2014.

SPRICIGO, D. A.; MATSUMOTO, S. R.; ESPÍNDOLA, M. L.; FERRAZ, S. M. Prevalência, quantificação e resistência antimicrobiana de sorovares de Salmonella isolados de lingüiça frescal suína. Ciência e Tecnologia de Alimentos, Campinas, v. 28, n. 4, p. 779-785, 2008 b. 
SPRICIGO, D. A.; MATSUMOTO, S. R.; ESPÍNDOLA, M. L.; VAZ, E. K.; FERRAZ, S. M. Prevalência e perfil de resistência a antimicrobianos de sorovares de Salmonella isolados de lingüiças suínas tipo frescal em Lages, SC. Arquivo Brasileiro de Medicina Veterinária e Zootecnia, Belo Horizonte, v. 60, n. 2, p. 517-520, 2008a.

VIEIRA, M. A.; SANTOS, L. F.; DIAS, R. C. B.; CAMARGO, C. H.; PINHEIRO, S. R. S.; GOMES, T. A. T.; HERNANDES, R. Atypical enteropathogenic
Escherichia coli as aetiologic agents of sporadic and outbreak-associated diarrhoea in Brazil. Journal of Medical Microbiology, Edinburgh, v. 65, n. 9, p. 9981006, 2016.

XAVIER, C.; GONZALES-BARRON, U.; PAULA, V.; ESTEVINHO, L.; CADAVEZ, V. Meta-analysis of the incidence of foodborne pathogens in Portuguese meats and their products. Food Research International, Essex, v. 55, n. 1, p. 311-323, 2014. 
